\title{
Gastric mucosal histamine and histamine methyltransferase in patients with duodenal ulcer
}

\author{
N R PEDEN, HELEN CALlaChAN, D M SHEPHERD, AND K G WORMSLEY* \\ From the Department of Pharmacology and Therapeutics, University of Dundee, Dundee
}

SUMMARY Histamine and histamine methyltransferase (HMT) have been measured in gastric mucosa from 110 patients with duodenal ulcer and 62 control subjects. Both antral and fundic mucosa had similar levels of HMT activity despite antral mucosa containing significantly less histamine. Patients with duodenal ulcer had significantly lower levels of fundic mucosal HMT activity and lower concentrations of fundic mucosal histamine than control subjects. An additional finding was that men who were cigarette smokers had significantly lower concentrations of fundic mucosal histamine (but not HMT) than non-smokers and, as there was an excess of cigarette smokers among patients with duodenal ulcer, this may be the explanation for the reduced concentrations of fundic mucosal histamine in these patients.

Histamine has long been known to be a potent gastric secretagogue 1 and its potential significance in the physiological control of gastric secretion has been emphasised by the recent finding that histamine $\mathrm{H}_{2}$-receptor antagonist drugs inhibit gastric secretion ${ }^{2}$ and will accelerate the healing of duodenal ulcers in $\operatorname{man}^{3}$. Despite this, the role of histamine in the pathogenesis of duodenal ulcer remains little understood and comparisons of gastric mucosal histamine in duodenal ulcer patients and control subjects have given conflicting results ${ }^{4}$. We have therefore studied histamine and its principal metabolising enzyme, histamine methyltransferase (HMT) (S-adenosyl-methionine: histamine-N-methyltransferase, E.C. 2.1.1.8) in the gastric mucosa of a large number of patients with and without endoscopically confirmed duodenal ulcer.

\section{Methods}

PATIENTS

The study received the approval of the Hospital Ethics Committee and patients gave informed consent. A total of 172 patients comprising outpatients with dyspeptic symptoms referred by hospital physicians for diagnostic upper gastrointestinal endoscopy have been studied. No patient had been taking ulcer-healing drugs other than occasional antacids at the time of

*Address for correspondence: Dr K G Wormsley, Department of Therapeutics, Ninewells Hospital and Medical School, Dundee DDI 9SY, Scotland.

Received for publication 16 June 1981 initial study or in the previous three months; nor was any patient taking anti-inflammatory drugs. No patient had undergone previous gastric surgery.

Based on the endoscopic findings, the patients were divided into four groups. (1) men with endoscopic duodenal ulcer but macroscopically normal stomachs -79 patients, mean age $43.8( \pm 1 \cdot 7)($ SEM) years; (2) women with endoscopic duodenal ulcer but macroscopically normal stomachs -31 patients, mean age $47.7( \pm 2.8)$ years; (3) men with macroscopically normal stomach and first part of duodenum-30 patients, mean age 46.2 ( \pm 2.6$)$ years; (4) women with macroscopically normal stomach and first part of duodenum -32 patients, mean age $49.5( \pm 3.0)$ years. The latter two groups of patients are termed 'non-ulcer dyspepsia' (NUD) in the text.

\section{ENDOSCOPY}

Each patient was premedicated with $0.6 \mathrm{mg}$ atropine given intramuscularly and sedated with $10-20 \mathrm{mg}$ diazepam given intravenously.

\section{GASTRIC MUCOSAL BIOPSIES}

Using flexible endoscopic biopsy forceps, six biopsies were taken from each patient at random along the greater curve from the rugose part of the stomach (fundus).

In addition, from 20 patients (10 men, 10 women, four with duodenal ulcer, 16 with NUD), four other biopsies were taken circumferentially from the midantrum of the stomach. The mean weight of biopsies was $4.15 \mathrm{mg}$ (range $0.92-8.68 \mathrm{mg}$ ). 


\section{TECHNIQUES}

\section{Preparation of homogenate}

Gastric mucosal biopsies were quickly weighed on a torsion balance and thoroughly homogenised in $0.5 \mathrm{ml}$ aminoguanidine-glucose solution at $0^{\circ} \mathrm{C}$ by means of a Jencon's hand homogeniser having a polytetrafluoroethylene tip. The aminoguanidine-glucose solution was prepared in $0.1 \mathrm{~mol} / 1$ sodium phosphate buffer, $\mathrm{pH} 7 \cdot 4$, and was $0.3 \mathrm{mmol} / \mathrm{l}$ with respect to aminoguanidine and $30 \mathrm{mmol} / \mathrm{l}$ with respect to glucose.

\section{Measurement of HMT activity}

The substrate solution was prepared by adding to $1 \mathrm{ml}$ of $0.2 \mathrm{mmol} / \mathrm{l} \mathrm{histamine}$ in $0.1 \mathrm{~mol} / \mathrm{l}$ sodium phosphate buffer, $\mathrm{pH} 7 \cdot 4,1 \mathrm{ml}$ of ring-14 C-histamine (specific activity $317 \mu \mathrm{Ci} / \mathrm{mg}$ ) equivalent to $15000 \mathrm{dps}$, dissolved in $0.01 \mathrm{~mol} / 1$ hydrochloric acid $(\mathrm{HCl}) .0 .1 \mathrm{ml}$ of this substrate was added to $0.1 \mathrm{ml}$ of tissue homogenate in a $15 \mathrm{ml}$ tapered centrifuge tube. After preincubation of the mixture for 10 minutes at $37^{\circ} \mathrm{C}$ in a shaking incubator, $0.1 \mathrm{ml}$ of $2.1 \mathrm{mmol} / 1 \mathrm{~S}$-adenosylmethionine (SAM) in $0 \cdot 1 \mathrm{~mol} / 1$ sodium phosphate buffer, $\mathrm{pH} 7 \cdot 4$, was added to start the reaction. The final concentrations of each reagent in the total volume of $0.3 \mathrm{ml}$ were histamine $(0.033 \mathrm{mmol} / \mathrm{l} ; 0.066 \mu \mathrm{Ci} / \mathrm{ml}), \quad \mathrm{SAM}$ $(0.7 \mathrm{mmol} / \mathrm{l})$, aminoguanidine $(0 \cdot 1 \mathrm{mmol} / \mathrm{l})$, and glucose $(10 \mathrm{mmol} / \mathrm{l})$. Incubation, with shaking, was continued for one hour, after which the reaction was stopped by the addition of $0.25 \mathrm{ml} 0.4 \mathrm{~mol} / 1$ perchloric acid containing $5 \mathrm{mmol} / \mathrm{l}$ methylhistamine (1-methyl-4- $\beta$ aminoethyl-imidazole). $0.6 \mathrm{ml}$ water, $0.2 \mathrm{ml} 10 \mathrm{~mol} / 1$ sodium hydroxide $(\mathrm{NaOH})$ and $4 \mathrm{ml}$ freshly purified chloroform were added, and the ${ }^{14} \mathrm{C}$-methylhistamine formed was extracted and counted as described by Beaven et al. ${ }^{6}$ The HMT activity was expressed as pmol methylhistamine formed per minute per $\mathrm{mg}$ protein $\left(\mathrm{pmol} \mathrm{min}^{-1} \mathrm{mg}\right.$ protein $\left.{ }^{-1}\right)$.

\section{Determination of protein concentration}

$0.1 \mathrm{ml}$ of tissue homogenate was diluted to $2 \mathrm{ml}$ with $0 \cdot 1 \mathrm{~mol} / 1$ phosphate buffer, $\mathrm{pH} 7 \cdot 4$, and centrifuged for 20 minutes at $26000 \mathrm{~g}$ and $0^{\circ} \mathrm{C}$. The protein content of the supernatant was determined by the method of Lowry et al. ${ }^{7}$

\section{Determination of histamine concentration}

$0.1 \mathrm{ml}$ of tissue homogenate was treated with $4.9 \mathrm{ml}$ of $0.4 \mathrm{~mol} / \mathrm{l}$ perchloric acid and centrifuged for 20 minutes at $26000 \mathrm{~g}$ and $0^{\circ} \mathrm{C}$. To $4 \mathrm{ml}$ of the resulting supernatant were added $1.5 \mathrm{~g}$ of lithium sulphate monohydrate, $0.5 \mathrm{ml} 5 \mathrm{~mol} / 1 \mathrm{NaOH}$, and $0.1 \mathrm{ml}$ of ring- ${ }^{14} \mathrm{C}$-histamine, equivalent to approximately $150 \mathrm{dps}$, in $0 \cdot 1 \mathrm{~mol} / 1 \mathrm{HCl}$. The ${ }^{14} \mathrm{C}$-histamine, which is too small in amount (approximately $0.054 \mathrm{nmol}$ ) to affect the subsequent fluorometric measurement, enables each sample to be individually corrected for losses occurring during the extraction process. The use of lithium sulphate, instead of the more commonly used sodium chloride to promote extraction of histamine from the aqueous to the chloroform layer, was introduced as sulphate ions produce much less quenching in the fluorometric measurement of histamine than do chloride ions. In all other respects the extraction of histamine and the subsequent spectrophotofluorometric determination of histamine followed the procedure of Shore et al. ${ }^{8} 0.1 \mathrm{ml}$ of the acid extract was placed in a vial for liquid scintillation counting so that a correction could be made for any histamine lost in the process.

Histamine concentrations throughout are expressed as $\mathrm{nmol} / \mathrm{g}$ (wet weight) of tissue. Conversion factor: histamine $1 \mathrm{nmol}=111 \mathrm{ng}$.

\section{STATISTICAL METHODS}

Unpaired Student's $t$ tests have been used for comparison between groups and the Wilcoxon signed ranks matched pairs test for within subject comparisons.

\section{Results}

COMPARISON OF HISTAMINE AND HMT IN BIOPSIES FROM ANTRUM AND FUNDUS (Table 1)

Histamine concentrations were significantly greater by $60 \%(\mathrm{P}>0.01)$ in fundic than antral mucosa. There was no difference in mucosal HMT activity between fundus and antrum.

COMPARISON OF FUNDIC MUCOSAL HISTAMINE AND HMT IN FOUR PATIENT SUBGROUPS (Table 2)

Frequency distributions are shown for histamine (Fig. 1) and HMT (Fig. 2) for men with duodenal ulcer. Men with duodenal ulcer have lower concentrations of mucosal histamine than men with NUD and this difference approaches statistical significance $(0 \cdot 1$ $>\mathrm{P}>0.05)$. A similar tendency is apparent for female duodenal ulcer patients who have lower fundic mucosal histamine concentrations than women with NUD but this difference is not statistically significant. Overall, patients with duodenal ulcer (data from men and women combined) have significantly lower concentrations of fundic mucosal histamine (mean 220.0 $\mathrm{nmol} / \mathrm{g} \pm 6.9$ ) than patients with NUD (data from men and women combined) (mean $250 \cdot 2 \mathrm{nmol} / \mathrm{g} \pm 10 \cdot 7$ ) $(\mathrm{P}>0 \cdot 05)$.

Both men $(P>0.02)$ and women $(P>0.05)$ with duodenal ulcer have significantly lower levels of fundic mucosal HMT than men or women with NUD and hence, overall, patients with duodenal ulcer (men and women combined) have significantly lower levels of fundic mucosal HMT activity (mean $42.2 \mathrm{pmol} \mathrm{min}^{-1}$ mg protein $\left.{ }^{-1} \pm 1 \cdot 1\right)$ than patients with NUD (men and women combined) (mean 49.2 $\pm 1 \cdot 6)(P>0 \cdot 01)$. 
Table 1 Gastric mucosal histamine and HMT in biopsies taken from antrum and fundus in 20 patients. Median and (range).

\begin{tabular}{|c|c|c|}
\hline & $\begin{array}{l}\text { Mucosal histamine } \\
\text { (nmol/g tissue) }\end{array}$ & $\begin{array}{c}\text { Mucosal HMT } \\
\left.\text { (pmol } \min ^{-1} \text { mg protein }-1\right)\end{array}$ \\
\hline Antrum & $\begin{array}{c}155 \cdot 9 \\
(105 \cdot 3-351 \cdot 0)\end{array}$ & $\begin{array}{c}53 \cdot 0 \\
(14 \cdot 0-101 \cdot 0)\end{array}$ \\
\hline Fundus & $\begin{array}{c}261 \cdot 0 \\
(149 \cdot 4-612 \cdot 0)\end{array}$ & $\begin{array}{c}49 \cdot 5 \\
(37 \cdot 3-86 \cdot 0)\end{array}$ \\
\hline
\end{tabular}

Table 2 Fundic mucosal histamine and HMT for four patient subgroups (mean values $\pm S E M$ )

\begin{tabular}{|c|c|c|c|}
\hline & \multicolumn{2}{|c|}{$\begin{array}{l}\text { Mucosal histamine } \\
\text { (nmol/g tissue) }\end{array}$} & $\begin{array}{c}\text { Mucosal HMT } \\
\left(\text { pmol } \min ^{-1} \text { mg protein }^{-1}\right)\end{array}$ \\
\hline \multicolumn{4}{|l|}{ Men } \\
\hline Duodenal ulcer (n & 79) & $219 \cdot 2 \pm 7 \cdot 9$ & $41 \cdot 8 \pm 1 \cdot 3$ \\
\hline NUD (n - 30) & & $253 \cdot 2 \pm 17 \cdot 9$ & $48 \cdot 4 \pm 2 \cdot 3$ \\
\hline \multicolumn{4}{|l|}{ Women } \\
\hline Duodenal ulcer ( $\mathrm{n}$ & 31) & $221 \cdot 9 \pm 14 \cdot 3$ & $42 \cdot 6 \pm 2 \cdot 2$ \\
\hline NUD (n 32) & & $247 \cdot 3 \pm 12 \cdot 2$ & $49 \cdot 9 \pm 2 \cdot 2$ \\
\hline
\end{tabular}

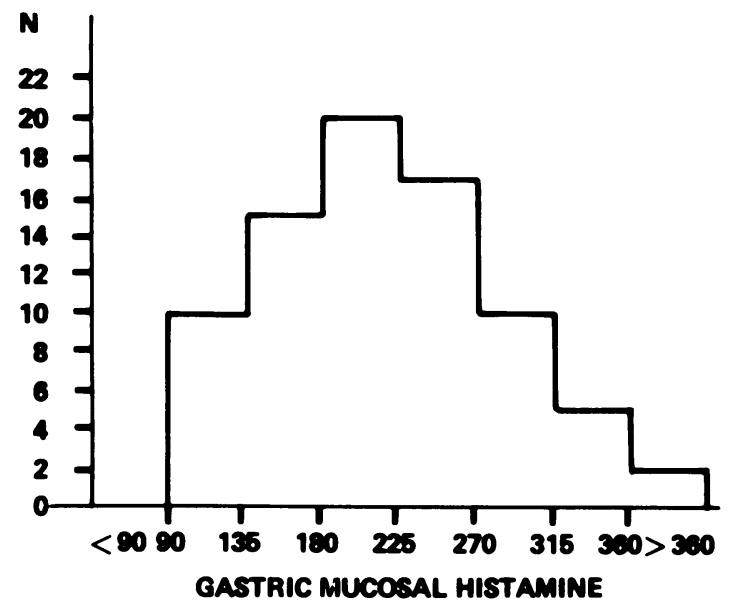

Fig. 1 Frequency distribution of gastric mucosal histamine (nmol/g tissue) in 79 men with duodenal ulcer. $N=$ number of subjects.

ANALYSIS OF FACTORS AFFECTING MUCOSAL HISTAMINE AND HMT

Age

There was no significant relationship between age and levels of fundic mucosal histamine or HMT activity.

$\operatorname{Sex}$

There was no significant difference between men and women with duodenal ulcer or NUD in the fundic mucosal histamine concentrations or levels of HMT activity.

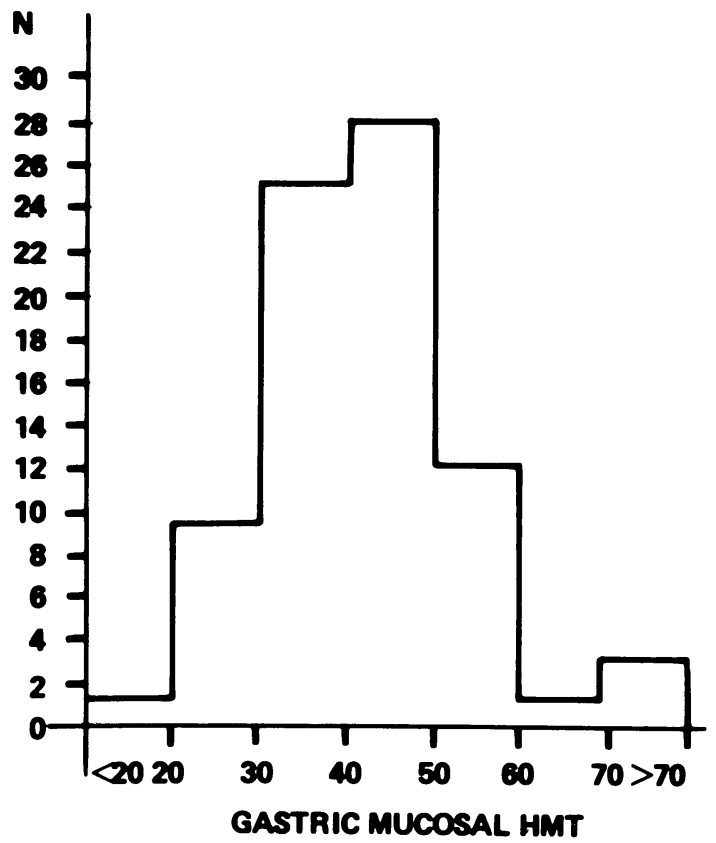

Fig. 2 Frequency distribution of gastric mucosal HMT

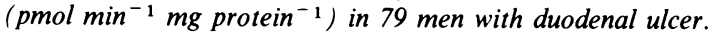
$N=$ number of subjects.

Cigarette smoking

One hundred and fifty patients could be classified as smokers or non-smokers at the time of study; 49 of 70 men with duodenal ulcer; 23 of 29 women with duodenal ulcer; 14 of 26 men with NUD; and eight of 25 women with NUD were habitual cigarette smokers.

Cigarette smokers had significantly lower levels of fundic mucosal histamine than non-smokers, for both men with duodenal ulcer $(P>0.05)$ and men with NUD $(\mathrm{P}>0.01)$ (Table 3). Among women, smokers also tended to have lower levels of fundic mucosal histamine in both duodenal and NUD groups, but these differences were not statistically significant.

Cigarette smoking did not appear to affect fundic mucosal HMT activity in any subgroup of patients (Table 4). Mean fundic mucosal histamine concentrations were then standardised to those expected if each of the subgroups contained the same proportions of cigarette smokers $(63 \%)$ and non-smokers $(37 \%)$ as the entire group of patients. When the standardised values and the observed values (Table 5) are compared, it can be seen that the differences between duodenal ulcer and NUD patients for both men and women become much smaller.

Relationship between fundic mucosal histamine and HMT A weak positive correlation between histamine and 
Table 3 Fundic mucosal histamine of non-smokers compared with smokers (mean values $\pm S E M$ )

\begin{tabular}{|c|c|c|}
\hline & \multicolumn{2}{|c|}{ Mucosal histamine (nmol/g tissue) } \\
\hline & Non-smokers & Smokers \\
\hline \multicolumn{3}{|l|}{ Men } \\
\hline Duodenal ulcer & $\begin{array}{c}239 \cdot 7 \pm 12 \cdot 8 \\
n=21\end{array}$ & $\begin{array}{c}205 \cdot 4 \pm 10 \cdot 5 \\
n \quad 49\end{array}$ \\
\hline NUD & $\begin{array}{c}285 \cdot 6 \pm 26 \cdot 8 \\
n=12\end{array}$ & $\begin{array}{c}196.4 \pm 15.7 \\
n=14\end{array}$ \\
\hline $\begin{array}{l}\text { Women } \\
\text { Duodenal ulcer }\end{array}$ & $\begin{array}{c}247 \cdot 8 \pm 46 \cdot 9 \\
n-6\end{array}$ & $\begin{array}{c}214 \cdot 4 \pm 15 \cdot 3 \\
n=23\end{array}$ \\
\hline NUD & $\begin{array}{c}254 \cdot 1 \pm 11 \cdot 7 \\
n=17\end{array}$ & $\begin{array}{c}237 \cdot 9 \pm 27 \cdot 9 \\
\text { n } \quad 8\end{array}$ \\
\hline
\end{tabular}

Table 4 Fundic mucosal HMT of smokers and non-smokers (mean values $\pm S E M)$

\begin{tabular}{|c|c|c|}
\hline & \multicolumn{2}{|c|}{ Mucosal $H M T\left(p m o l \min ^{-1}\right.$ mg protein -1$)$} \\
\hline & Non-smokers & Smokers \\
\hline \multicolumn{3}{|l|}{ Men } \\
\hline \multirow[t]{2}{*}{ Duodenal ulcer } & $42 \cdot 8 \pm 2 \cdot 2$ & $39.9 \pm 1 \cdot 7$ \\
\hline & n 21 & $\mathrm{n}=49$ \\
\hline \multirow[t]{2}{*}{ NUD } & $49 \cdot 4=3.9$ & $49 \cdot 2 \pm 3 \cdot 1$ \\
\hline & n 12 & n 14 \\
\hline \multicolumn{3}{|l|}{ Women } \\
\hline Duodenal ulcer & $\begin{array}{c}39 \cdot 6 \pm 4 \cdot 3 \\
n=6\end{array}$ & $\begin{array}{c}42 \cdot 6 \pm 2 \cdot 5 \\
n-23\end{array}$ \\
\hline \multirow[t]{2}{*}{ NUD } & $50 \cdot 6 \pm 4 \cdot 0$ & $50 \cdot 9 \pm 2 \cdot 1$ \\
\hline & n 17 & n 8 \\
\hline
\end{tabular}

Table 5 Comparison of fundic mucosal histamine standardised* for smoking habits of entire population studied, with observed values for each subgroup

\begin{tabular}{|c|c|c|}
\hline & \multicolumn{2}{|c|}{$\begin{array}{l}\text { Mucosal histamine (nmol/g tissue) } \\
\text { mean value } \pm S E M\end{array}$} \\
\hline & Standardised & Observed \\
\hline \multicolumn{3}{|l|}{ Men } \\
\hline Duodenal ulcer & $218 \cdot 1 \neq 8 \cdot 0$ & $215 \cdot 7 \pm 8 \cdot 3$ \\
\hline NUD & $229 \cdot 4 \pm 13 \cdot 9$ & $237 \cdot 6 \pm 15 \cdot 0$ \\
\hline \multicolumn{3}{|l|}{ Women } \\
\hline Duodenal ulcer & $226 \cdot 8 \pm 19 \cdot 8$ & $221 \cdot 3 \pm 15 \cdot 5$ \\
\hline NUD & $243.9 \pm 18 \cdot 1$ & $248 \cdot 9 \pm 12 \cdot 0$ \\
\hline${ }^{*}$ Standardised $\mathrm{x}$ & \multicolumn{2}{|c|}{$0.63 \times($ smokers $)+0.37 \times($ non-smokers $)$} \\
\hline
\end{tabular}

HMT was found in men with duodenal ulcer. This relationship was expressed by the equation $y=0.052 \mathrm{x}$ $+30 \cdot 4$, where $\mathrm{y}=\mathrm{HMT}$ activity and $\mathrm{x}=$ histamine concentration $(r=0.31 ; \mathrm{P}>0.01)$. No such relationship was apparent for the other three subgroups (women with duodenal ulcer, $r=0 \cdot 06$, men with NUD, $r=-0.21$, women with NUD, $r=-0.03$ ).

\section{Discussion}

COMPARISON OF HISTAMINE AND HMT IN FUNDIC AND ANTRAL MUCOSA

This study has shown that mucosal histamine levels are significantly greater in fundic than antral mucosa, confirming the findings of Lorenz et al. ${ }^{9}$ Levels of mucosal HMT activity from fundus and antrum do not appear to have been compared previously in man, and it is therefore of interest that the activity of the principal histamine-metabolising enzyme is similar in antral and fundic mucosa in view of the $60 \%$ difference in histamine concentrations, suggesting that the control and function of mucosal histamine differs in fundus and antrum.

\section{FUNDIC MUCOSAL HMT}

In the present study there are small but consistent and highly significant differences in the levels of fundic mucosal HMT activity between duodenal alcer and NUD patients, the levels in duodenal ulcer patients being lower by $14 \%$. This finding is independent of age, sex, and cigarette smoking. Our findings confirm the report of Barth et al., 6 who, in a smaller study of 15 patients and 18 controls, found levels of HMT activity to be $15 \%$ lower in the duodenal ulcer group. The functional significance of the reduced HMT activity in duodenal ulcer patients remains unexplained but it clearly does not cause increased mucosal concentrations of histamine which might be expected to increase acid secretion. Indeed, in men with duodenal ulcer, HMT activity was positively correlated with mucosal histamine.

\section{FUNDIC MUCOSAL HISTAMINE CONCENTRATIONS}

We have found that patients with duodenal ulcer have significantly lower gastric mucosal histamine concentrations than patients with NUD. However, the lower histamine concentrations bordered on statistical significance only when one considered male patients and not the female patients. Troidl et al. 4 in a smaller study of 18 patients with duodenal ulcer $(17$ men and one woman) and 31 controls (21 men and 10 women) found that duodenal ulcer patients had mucosal histamine concentrations $30 \%$ lower than controls. Patients in this latter study were, like ours, premedicated for endoscopy and a similar histamine assay was used. In contrast, in a study of nine patients (five with duodenal ulcer and four normal subjects), Domschke et al. 5 found higher mucosal histamine concentrations in duodenal ulcer patients than controls. In that study patients were not premedicated and an isotopic enzymatic assay for histamine was used.

Further analysis of our results seems to indicate the possibility that the difference in fundic mucosal histamine levels between men with duodenal ulcer and 
NUD may be apparent, rather than related to the ulcer disease. The two groups differ in cigarette smoking habits and, as our results show that, in men, nonsmokers had significantly higher mucosal histamine concentrations than did smokers, irrespective of the presence or absence of duodenal ulceration, it may be that the differences in proportion of cigarette smokers in the duodenal ulcer and NUD groups account for most of the observed differences in mucosal histamine concentrations between the two groups. A similar effect has not been established in our female patients but the number of patients in two of the female subgroups (non-smokers with duodenal ulcer and smokers with NUD) was small (six and eight respectively), so that a real effect may have been obscured. Cigarette smoking as a possible influence on fundic mucosal histamine levels has not been commented on in previously reported studies. 45

In conclusion, in a study of 110 patients with duodenal ulcer and 62 controls with non-ulcer dyspepsia we have shown that fundic mucosal HMT activity is consistently lower in patients with duodenal ulcer. Fundic mucosal histamine concentrations were lower in male patients with duodenal ulcer than NUD, perhaps because more ulcer patients smoked cigarettes, as men who were cigarette smokers had significantly lower fundic mucosal histamine concentrations than did non-smokers.

Mr Simon Ogston, Department of Occupational and Community Medicine, provided advice on statistical analysis and Mrs Lynn Connolly secretarial assistance. Dr K G Wormsley gratefully acknowledges a research grant from the Scottish Hospital Endowments Research Trust.

\section{References}

1 Popielski J. $\beta$-imidazolyläthylamin und die Organextrakte I. Pflugers Archiv 1920; 178:214-36.

${ }^{2}$ Black JW, Durant CJ, Ganellin CR, Parsons EM. Definition and antagonism of histamine $\mathrm{H}_{2}$-receptors. Nature 1972; 236:385-90.

${ }^{3} \mathrm{~A}$ multicentre trial. Treatment of duodenal ulcer by metiamide. Lancet 1975; 779-81.

${ }^{4}$ Troidl H, Lorenz W, Rohde H, Hafner G, Ronzheimer M. Histamine and peptic ulcer: a prospective study of mucosal histamine concentration in duodenal ulcer patients and in control subjects suffering from various gastrointestinal diseases. Klin Wschr 1976; 54:947-56.

${ }^{5}$ Domschke W, Subramanian N, Mitznegg P, Baenkler HW, Domschke S, Wunsch E. Gastric mucosal histamine in duodenal ulcer patients: release by secretin. Acta Hepato-Gastroenterol 1977; 24:444-6.

6 Beaven MA, Jacobsen S, Horakova Z. Modification of the enzymatic isotopic assay of histamine and its application to measurement of histamine in tissues. Clin Chim Acta 1972; 37:91-103.

${ }^{7}$ Lowry OH, Rosebrough NH, Farr AL, Randall RJ. Protein measurement with the Folin phenol reagent. $J$ Biol Chem 1951; 193: 265-75.

${ }^{8}$ Shore PA, Burkhalter A, Eohn VH. A method for the fluorometric assay of histamine in tissues. $J$ Pharmacol Exp Ther 1959; 127:182-6.

${ }^{9}$ Lorenz W, Troidl H, Barth H, Rohde H. In: Ereutzfeldt $\mathrm{W}$, ed. Proceedings of an international symposium on histamine $\mathrm{H}_{2}$-receptor antagonists. Amsterdam: Excerpta Medica, 1978; P6.

${ }^{10}$ Barth H, Troidl H, Lorenz W, Rohde H, Glass R. Histamine and peptic ulcer disease: histamine methyltransferase activity in gastric mucosa of control subjects and duodenal ulcer patients before and after surgical treatment. Agents Actions 1977; 7:75-9. 
ever-expanding subject which, from early student days, often seems to be clouded by mystique.

The layout and concise style are excellent and the content provides a refreshing insight into hepatology, with accepted dogma tempered throughout by the reality of every-day clinical experience. There is a generally critical approach to the more controversial areas of management, such as chronic active hepatitis, primary biliary cirrhosis, and portal hypertension. The chapter on immunology in liver disease is commendably concise and all that is needed by most clinicians.
No mention is made of nutritional aspects such as the new field of branch chain amino-acid therapy, or the role of ultrasound in diagnostic and therapeutic aspiration of liver abscesses. Also the advice concerning 'appropriate' antibiotics for liver abscesses is inadequate and Child's classification could have been properly described. The book is surprisingly up to date and overall is a valuable complementary addition of the tradition excellent large British texts on liver disease. I can recommend it wholeheartedly.

B J M JONES

\section{Books received}

Aspects of Gastroenterology for Nurses Edited by Mary Sykes. (Pp. 241. Illustrated. £17.50.) Pitman Medical: London. 1981.

Gastric Secretion: Basic and Clinical Aspects Edited by Stanislaw J Konturek and Wolfram Domschke. (Pp. 123. Illustrated. Price not stated.) Thieme: Stuttgart. 1981.

Stomach Diseases. Current Status. Edited by Y M F van Maercke, E M J van Moer, P A R Pelckmans. International Congress Series 555. (Pp. 434. Illustrated. \$76.50.) Excerpta Medica: Amsterdam. 1981.

\section{Corrections}

Ileal dysfunction in Crohn's disease assessed by the postprandial serum bile acid response by F J Suchy and W F Balistreri, Gut 1981;22:948-52. In the legends of Figs 2 and 3, the units should $\mathrm{read} \mu \mathrm{mol} / \mathrm{l}$, not $\mathrm{mmol} / \mathrm{l}$. In the last paragraph of the Results section, the integrated area under the meal response curve should be $\mu \mathrm{mol} / \mathrm{l} . \mathrm{h}$ and not $\mu \mathrm{mol} / \mathrm{l} / \mathrm{h}$.

Gastric mucosal histamine and histamine methyltransferase in patients with duodenal ulcer by $\mathbf{N} \mathbf{R}$ Peden, Helen Callachan, D M Shepherd, and K G Wormsley, Gut 1982; 23:58-62. All the signs indicating the $P$ values in this article were printed as greater than and should have indicated less than the appropriate value, except for $0.1>P>0.05$ on page 59. 